\title{
Protein pattern changes induced by culture filtrate of Pseudomonas syringae pv. phaseolicola in bean (Phaseolus vulgaris L.) explants cultured in vitro
}

\author{
Ana Isabel GonzÁLEZ, Carlos PolAnco, and María Luisa RuIz* \\ Area de Genética, Facultad de Biología, Universidad de León, 24071 León, Spain
}

(Received 29 February 2000; accepted 15 May 2000)

\begin{abstract}
Cotiledonary node explants of two bean cultivars were cultured in vitro in a medium supplemented with filtrate from liquid cultures of race 1 of the bean pathogen Pseudomonas syringae pv. phaseolicola in order to study changes in gene expression induced by elicitors present in the filtrate. The protein patterns of explants from cultivars Palmeña (susceptible to the pathogen race 1) and Red Mexican (resistant to race 1) cultured for 3 and 5 days in filtratefree and filtrate-supplemented media have been obtained by two-dimensional polyacrylamide gel electrophoresis (2-D PAGE) and comparison made between them. On the basis of their reproducibility, 550 polypeptides were scored and 58 of them showed differences among the treatments. These differences revealed possible changes in gene expression associated to stress and/or presence of filtrate, and a differential response between the cultivars susceptible and resistant to the pathogen.
\end{abstract}

Phaseolus vulgaris / Pseudomonas syringae pv. phaseolicola / 2-D PAGE / in vitro culture / gene expression

Résumé - Modifications du patron protéique induites par le filtrat de culture de Pseudomonas syringae pv. phaseolicola chez des explants de haricot (Phaseolus vulgaris L.) cultivés in vitro. Des explants de nœuds cotylédonnaires de 2 variétés de haricot ont été cultivés «in vitro» dans un milieu supplémenté avec un filtrat liquide provenant de la race 1 du pathogène Pseudomonas syringae pv. phaseolicola pour étudier les altérations d'expression des gènes induites par l'éliciteur présent dans le filtrat. Les diagrammes protéiques des explants issus de : Palmeña (sensible à la race 1 du pathogène) et de Red Mexican (résistante à la race 1) cultivés durant 3 et 5 jours dans un milieu sans et avec filtrat bactérien, obtenus par électrophorèse bidimensionnelle (2-D PAGE), ont été comparés entre eux. On a observé 550 polypeptides reproductibles, 58 d'entre eux ont montré des différences entre les différents traitements qui révèlent des possibles changements dans l'expression des gènes associés au stress et/ou à la présence du filtrat et ce entre les cultures résistantes et sensibles au pathogène.

Phaseolus vulgaris / Pseudomonas syringae pv. phaseolicola / 2-D PAGE / culture in vitro / expression génétique

Communicated by Nicolás Jouve (Alcalá de Henares, Spain)

* Correspondence and reprints

degmrs@unileon.es 


\section{Introduction}

Halo-blight disease of bean (Phaseolus vulgaris L.) caused by the bacterium Pseudomonas syringae pv. phaseolicola is a seedborn disease widespread in Europe, and in North and Southern America. This plant pathogen is often the cause of significant reductions in crop yield and quality of beans. Resistance to halo-blight was first demonstrated in the cultivar Mexican Red [20]. Later, Walker and Patel [40] showed that a new race of the pathogen emerged able to attack Red Mexican (a derivative of Mexican Red); thus, this cultivar became the differential for races 1 and 2 being resistant to race 1 but susceptible to race 2. More recently, isolates of $P$. s. pv. phaseolicola from Africa and other bean growing areas were categorized into nine races on the basis of their reactions to eight differential cultivars following artificial inoculation [36]. The resistant trait is associated with a hypersensitive reaction (HR). The mechanism(s) by which plants could restrict bacterial replication and transport are not well-understood. However, several anatomical and biochemical changes accompany this hypersensitive defense response [33]. Outstanding among these are an increased synthesis and/or accumulation of a spectrum of proteins termed pathogenesis-related (PR) proteins [1].

There are numerous reports in the literature of changes in proteins in a plant after infection with a pathogen $[19,30]$. In bean, PR proteins have been induced in french bean (Phaseolus vulgaris) and lima bean ( $P$. lunatus) leaves infected with a virus $[8,27,34]$ and fungi $[5,7]$. The induction of PR proteins is not an exclusive pathogen-specific response because these proteins are synthesized under different stress conditions, and the elicitoractive molecules are chemically diverse: glycans, glycoproteins and lipids isolated from fungal and bacterial cell walls and culture filtrates, and a variety of structurally unrelated, artificial inducers [6, 10]. In fact, exposure of bean leaves to mercuric chloride or ethylene induces PR proteins $[8,38]$. Different authors have observed protein differences between host lines that are resistant or susceptible after infection by a given pathogen [31], and attempts have been made to associate these protein changes with a resistance gene [15]. Slusarenko and Longland [35] observed that the hypersensitive reaction produced in Phaseolus vulgaris cv. Red Mexican after infection with Pseudomonas syringae pv. phaseolicola race 1 (resistant reaction) is associated with the appearance of polypeptides, some of them not detected when Red Mexican leaves were inoculated with race 2 (susceptible reaction).

Two-dimensional polyacrylamide gel electrophoresis (2-D PAGE) based on the method of O'Farrel [29] is currently the chosen method for the separation of complex protein mixture from whole cells or tissues [12]. These gel patterns not only reveal the amounts of proteins but also many of the post-translational modifications they have undergone. With this technique it has been possible to identify, with a high degree of certainty, the products of a given gene [32].

Experimental models using cultured plant cells and elicitor preparation from pathogens have proven to be good tools for the identification and isolation of putative defense-related genes [13, 39, 43]. The mRNA's activities for many of the enzymes of the biosynthetic pathway of isoflavonoid phytoalexins have been shown to increase in elicitor-treated cell suspension cultures of bean [5, 7]. More recently, it has been shown that fungal elicitor-treatment of bean (P. vulgaris) cell suspension cultures induces two PR proteins whose cDNAs have been sequenced [43]. On the other hand, in many studies bacterial culture filtrates have been used as selective agents especially when the filtrate exhibits phytotoxic activity $[3,17]$. Hartman et al. [18] using cultivars of $P$. vulgaris susceptible and resistant to $P$. $s$. pv. phaseolicola observed a significative correlation between in vitro resistance to the filtrate of $P$. s. pv. phaseolicola and resistance to the pathogen. The aim of our study was to explore the changes of protein patterns in cotyledonary node explants of Phaseolus vulgaris cvs. Palmeña (susceptible to Pseudomonas syringae pv. phaseolicola race 1) and Red Mexican (resistant to race 1) when these explants were cultured on a medium supplemented 
with filtrate of $P$. s. pv. phaseolicola race 1 for 3 and 5 days, in order to detect a differential in vitro response associated with the reaction of these cultivars to the pathogen at the level of the whole plant. Analysis of two-dimensional protein patterns was chosen to identify specific markers of filtrate elicitation.

\section{Materials and methods}

\subsection{Elicitor preparation}

Isolates of Pseudomonas syringae pv. phaseolicola race 1, provided by S.I.A. (Servicio de Investigaciones Agrarias, Junta de Castilla y León, Spain) and isolated in Valladolid (Spain), were grown in King medium B [23] for 3 days at $25^{\circ} \mathrm{C}$ in an orbital shaker (250 rpm). $10 \mathrm{ml}$ of this culture, turbidometrically standardized at $10^{8} \mathrm{cfu} \cdot \mathrm{ml}^{-1}$ was used to inoculate 11 of M9 medium [25]. After 10 days in an orbital shaker at $250 \mathrm{rpm}$ and $18{ }^{\circ} \mathrm{C}$, the M9 culture was centrifuged at $5000 \mathrm{rpm}$ for $20 \mathrm{~min}$ and the supernatant was filtrated through a $0.45 \mu \mathrm{m}$-pore diameter Millipore filter.

\subsection{In vitro culture}

Phaseolus vulgaris L. cvs. Palmeña and Red Mexican which are susceptible and resistant, respectively, to the infection with Pseudomonas syringae pv. phaseolicola race 1, were chosen for the present study. Seeds of these cultivars were surface sterilized with bleach and placed in sterile flasks containing wet sterile cotton. After 8 days, cotyledonary nodes were excised from seedlings as described by Vaquero et al. [37] and then placed on the culture media. The culture media consisted of Murashige and Skoog [28] medium with $30 \mathrm{~g} \cdot \mathrm{l}^{-1}$ sucrose and $2 \mathrm{mg} \cdot \mathrm{l}^{-1}$ 2,4-dichlorophenoxiacetic acid $(2,4-\mathrm{D})$ with or without $30 \%(\mathrm{v} / \mathrm{v})$ bacterial culture filtrate. These media have been named MSD-fil, for the medium supplemented with filtrate, and MSD, for the filtrate-free medium. Media were adjusted to $\mathrm{pH} 5.6$ prior to adding $10 \mathrm{~g} \cdot \mathrm{l}^{-1}$ agar and autoclaved at $124^{\circ} \mathrm{C}$ for $20 \mathrm{~min}$.
The bacterial filtrate was added to the medium culture (MSD-fil) after the medium had been autoclaved and cooled to $50{ }^{\circ} \mathrm{C}$. Culture conditions have been previously described [37]. Protein pattern analyses were conducted with 3 and 5 day old cultures, since in a previous work [14] we have detected polypeptide changes in cotyledonary node explants of Phaseolus vulgaris after 4 days in culture, and PR proteins were detectable in primary leaves of $P$. vulgaris at about 3 days after viral infection [27].

\subsection{Two-dimensional protein electrophoresis}

Total proteins were extracted from one gram of lyophilized cotyledonary node pieces according to Bauw et al. [4] after 3 or 5 days in culture on MSD or MSD-fil media. Proteins were solubilized in the O'Farrel lysis buffer until a final protein concentration of $1 \mathrm{mg} \cdot \mathrm{ml}^{-1}$. The method of O'Farrel [29] with slight modifications was used to perform 2-D PAGE. A $70 \mu \mathrm{g}$ sample of protein was loaded for the first dimension in a isoelectro focusing (IEF) 4-7 $\mathrm{pH}$ gradient gel (4\% acrylamide-bisacrylamide; $9.5 \mathrm{M}$ urea; 5\% carrier ampholytes and $20 \%$ Nonidet P-40). After prefocusing the gels, electrophoresis was carried out at $600 \mathrm{~V}$ for 15 hours and $800 \mathrm{~V}$ for 1 hour. The first-dimension gels were equilibrated for $30 \mathrm{~min}$ in a $0.0625 \mathrm{M}$ Tri-HCl buffer pH 6.8 with $2.3 \%$ (w/v) SDS, $0.5 \%$ (v/v) 2-mercaptoethanol and $1 \%$ glycerol. Proteins were separated in the second dimension by SDSPAGE using a $12 \%$ acrylamide running (separating) gel and 5\% acrylamide stacking gel $(1.0 \mathrm{~mm}$ thick). Gels were run with cooling at $35 \mathrm{~mA}$ for 5-6 hours with a voltage limit of $200 \mathrm{~V}$. After electrophoresis the gels were fixed and then silverstained [26]. A silver-stained 2-D gel is shown in Figure 1. An average of 550 spots were analyzed in each 2-D gel. Gels obtained from cotyledonary node explants cultured on MSD-fil medium were compared to the control gels (explants cultured on MSD) by superposing transparent films. The reported results were obtained after observation of at least four well defined gels of at least two extractions for each time in culture and culture medium tested. Only the appearance or 
disappearance of specific polypeptides which were shown to be qualitatively consistent in their expression were identified.

\section{Results}

In vitro toxic activity of the bacterial filtrate from Pseudomonas syringae pv. phaseolicola race 1 cultures used in this work was tested previously using cotyledonary node explants of cvs. Palmeña and Red Mexican that were placed on media supplemented with $30 \%$ filtrate (MSD-fil) and filtrate-free medium (MSD). All the explants cultured on MSD formed callus after 1 month of culture. The explants of Palmeña (cv. susceptible to the pathogen P. s. pv. phaseolicola race 1) cultured on MSD-fil medium formed calli with a drastic growth reduction and brownish aspect. In contrast, the explants of Red Mexican (cv. resistant to the race 1 of $P$. s. pv. phaseolicola) cultured on MSD-fil medium presented, after 1 month in culture, a callus formation similar to those observed when the explants were placed on the MSD medium (data not shown).

In order to analyze the early changes induced by the bacterial filtrate in the protein pattern of cotyledonary node explants of cvs. Palmeña and Red Mexican, soluble proteins were extracted from explants cultured in vitro for 3 or 5 days and were analyzed using 2-D PAGE. For each cultivar, the gels corresponding to explants cultured for 3 and 5 days on MSD-fil medium were compared against the gels obtained from cultured explants on medium without filtrate (MSD) during the same period of time. Protein patterns of explants cultured for 5 days on medium with filtrate were also compared against explants cultured for 3 days on the same medium. All explants analyzed (after 3 or 5 days in culture) did not shown any visible signs of toxicity.

Using high quality gels, as that showed in Figure 1, a map of all spots appearing on the gels was drawn for each period of time in culture, and the culture medium tested. To eliminate poorly reproducible spots and some artifacts, we discarded all spots that did not appear in at least four gels

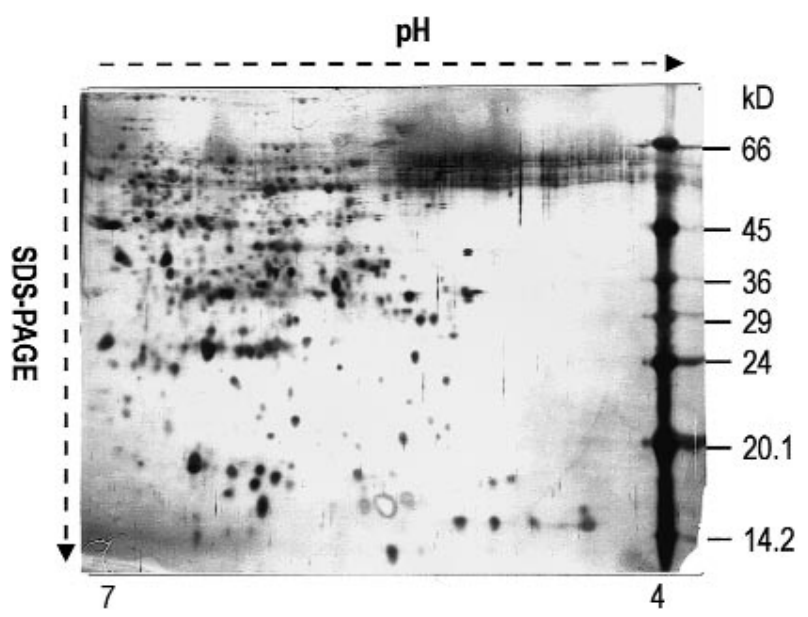

Figure 1. A typical 2-D gel obtained after separation by isoelectric focusing and SDS-PAGE and silver-staining of seventy micrograms of total protein extract obtained from lyophilized cotyledonary node explants.

of each treatment. On the basis of their reproducibility 550 spots were scored. The comparative studies revealed a set of 58 differences among polypeptides (Tab. I): 37 of them were observed in explants of Palmeña, 30 of them were found in explants of Red Mexican, and nine were common to both cultivars. All polypeptides were characterized by their isoelectric point and molecular weight.

Figure 2 diagrammatically shows all the changes in protein patterns detected in explants of cvs. Palmeña and Red Mexican after 3 (Fig. 2A) and 5 (Fig. 2B) days in culture, as well as the changes in protein patterns observed when explants cultured for 5 days on the medium with filtrate are compared to explants cultured for 3 days on the same medium (Fig. 2C). After 3 days of culture (Fig. 2A), 16 changes were found in explants of the cv. Palmeña: seven polypeptides were only seen in explants cultured on MSD-fil, while the filtrate induced the loss of nine polypeptides. In the same conditions explants of the cv. Red Mexican showed ten changes: four polypeptides appeared and six polypeptides disappeared in explants cultured in presence of filtrate with respect to those explants cultured on the filtrate-free medium. Only three of these polypeptides presented the same 
Table I. Polypeptides which showed a differential expression.

\begin{tabular}{|c|c|c|c|c|c|c|c|c|c|}
\hline \multirow{2}{*}{$\begin{array}{l}\text { Protein } \\
\text { number }\end{array}$} & \multicolumn{2}{|c|}{ Palmeña } & \multicolumn{2}{|c|}{ Red Mexican } & \multirow{2}{*}{$\begin{array}{l}\text { Protein } \\
\text { number }\end{array}$} & \multicolumn{2}{|c|}{ Palmeña } & \multicolumn{2}{|c|}{ Red Mexican } \\
\hline & $\mathrm{kDa}$ & $\mathrm{pI}$ & $\mathrm{kDa}$ & $\mathrm{pI}$ & & $\mathrm{kDa}$ & $\mathrm{pI}$ & $\mathrm{kDa}$ & $\mathrm{pI}$ \\
\hline 1 & & & 64.8 & 6.5 & 30 & & & 33.3 & 4.9 \\
\hline 2 & 59.4 & 6.6 & & & 31 & 32.8 & 5.3 & 32.8 & 5.3 \\
\hline 3 & 59.4 & 5.2 & & & 32 & 32.3 & 5.9 & & \\
\hline 4 & 59.4 & 5.1 & & & 33 & & & 31.3 & 5.9 \\
\hline 5 & 58.2 & 5.5 & & & 34 & & & 31.3 & 5.8 \\
\hline 6 & & & 57.1 & 5.7 & 35 & 29.5 & 5.1 & 29.5 & 5.1 \\
\hline 7 & & & 57.1 & 5.6 & 36 & 27.4 & 5.9 & & \\
\hline 8 & & & 57.1 & 4.8 & 37 & & & 27.0 & 6.4 \\
\hline 9 & & & 56.0 & 6.1 & 38 & 27.0 & 5.8 & & \\
\hline 10 & 55.6 & 6.6 & & & 39 & 26.9 & 6.2 & & \\
\hline 11 & & & 52.8 & 6.0 & 40 & & & 26.3 & 6.3 \\
\hline 12 & & & 52.8 & 5.9 & 41 & 24.8 & 6.0 & 24.8 & 6.0 \\
\hline 13 & 50.8 & 6.0 & 50.8 & 6.0 & 42 & 24.8 & 4.4 & & \\
\hline 14 & 50.8 & 4.7 & & & 43 & 24.5 & 6.3 & & \\
\hline 15 & 50.8 & 4.6 & & & 44 & 24.5 & 4.8 & & \\
\hline 16 & 48.9 & 5.4 & & & 45 & 23.8 & 6.2 & & \\
\hline 17 & 48.9 & 5.3 & & & 46 & 23.5 & 6.0 & & \\
\hline 18 & 48.0 & 5.4 & & & 47 & & & 23.2 & 5.5 \\
\hline 19 & 48.0 & 5.3 & & & 48 & & & 22.9 & 5.0 \\
\hline 20 & 44.7 & 6.1 & & & 49 & 22.2 & 6.0 & 22.2 & 6.0 \\
\hline 21 & 44.4 & 5.3 & 44.4 & 5.3 & 50 & 21.4 & 6.6 & 21.4 & 6.6 \\
\hline 22 & 42.4 & 6.4 & 42.4 & 6.4 & 51 & & & 20.8 & 6.4 \\
\hline 23 & & & 41.7 & 6.4 & 52 & 20.5 & 5.6 & 20.5 & 5.6 \\
\hline 24 & 39.7 & 6.3 & & & 53 & & & 19.4 & 6.0 \\
\hline 25 & 39.7 & 5.1 & & & 54 & & & 18.7 & 6.4 \\
\hline 26 & 36.9 & 5.4 & & & 55 & & & 18.7 & 5.7 \\
\hline 27 & 34.3 & 6.0 & & & 56 & & & 18.7 & 5.3 \\
\hline 28 & 33.8 & 6.5 & & & 57 & 15.6 & 6.0 & & \\
\hline 29 & & & 33.3 & 5.0 & 58 & 14.2 & 4.6 & & \\
\hline
\end{tabular}

characteristics in the two cultivars studied (\# 31, 35 and 50).

A large number of changes was detected in the protein patterns after 5 days of culture (Fig. 2B). In this case, explants of Palmeña showed 18 changes: nine of them were newly observed proteins in explants cultured on the MSD-fil medium, while other nine polypeptides were not observed. In explants of Red Mexican 14 changes were observed: six present and eight absent were seen in explants cultured on the MSD-fil medium when compared to explants cultured on the MSD medium. From all the changes observed only three showed the same characteristics in both cultivars (\# 21, 41 and 49). When comparison among explants cultured for 3 and 5 days on MSD-fil medium was realized (Fig. 2C) there were eight and seven polypeptides changed in explants of Palmeña and Red Mexican, respectively. All these polypeptides were present in 3 day old cultured explants on the medium with filtrate, but disappeared after 5 days in culture. None of these spots showed the same characteristics in both cultivars. 


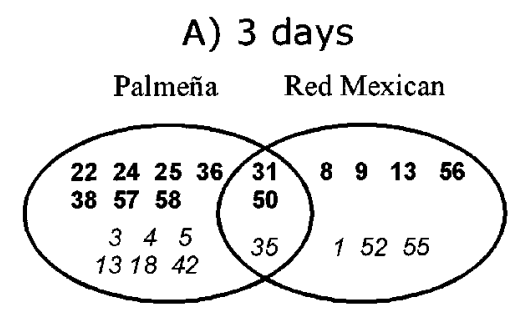

B) 5 days

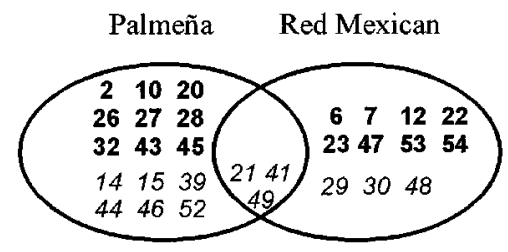

C) 5 days vs. 3 days

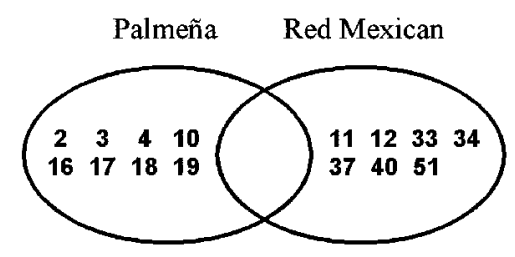

Figure 2. Changes in protein patterns of cotyledonary node explants of cultivars Palmeña and Red Mexican after 3 days (A) and 5 days (B) in in vitro culture on medium supplemented with $P$. syringae pv. phaseolicola bacterial filtrate when compared against explants cultured on the control medium; and changes in protein pattern when explants cultured for 5 days on filtrate-supplemented medium are compared against explants cultured for 3 days on the same medium (C). Bold figures indicate not observed proteins and italic figures indicate newly observed proteins. Molecular weight and $\mathrm{pI}$ of the proteins are indicated in Table I.

\section{Discussion}

All the observed reproductible proteic changes shown in Table I have been classified into four major groups for a better comprehension (Fig. 3).

Group I: Polypeptide changes associated to stress. Some polypeptides were observed in cotyle- donary node explants of Palmeña and Red Mexican after 3 days in culture irrespective of the culture medium tested (whether supplemented with filtrate (MSD-fil) or not (MSD)), but they were undetectable in explants after 5 days in culture. These are probably polypeptides that were affected by exposure of explants to the stress produced by in vitro culture. It is known that the in vitro condition is itself a stress condition since excised explants are generally used and the explants are always cultured under artificial conditions, and also that gene expression can change in response to phytohormones and/or wounding [11, 14]. It has been described that pathogenesis-related proteins are expressed in response to physical, chemical and stress factors including plant-hormones such as those frequently used in in vitro tissue culture [2, $16,21]$. In this work, excised explants are used and the two media utilized (MSD and MSD-fil) contained 2,4-D to induce cell division.

Group II: Polypeptide changes associated to stress and filtrate. Some polypeptides were observed in explants cultured on the medium with filtrate both at 3 and 5 days, but they were also present in explants cultured on the filtrate-free medium only at 3 days (subgroup IIb) or 5 days (subgroup IIa). This response would be expected if the filtrate induced an earlier appearance (IIa) or maintained the gene expression for more time (IIb). Changes in gene expression, including the induction of PR proteins, can be induced in cultured bean plant cells by fungal elicitors [13, 43]. A polypeptide observed in explants of $\mathrm{cv}$. Red Mexican (64.8 kDa-6.5 pI, IIa) has a molecular mass similar to a polypeptide $(64.9 \mathrm{kDa}-6.4 \mathrm{pI})$ isolated from fungal elicitor-treated bean cells, which was firstly identified as cinnamyl-alcohol dehydrogenase (CAD) one enzyme specific to the synthesis of lignin [41], although later, due to the extensive sequence similarity of this bean CAD with a maize malic enzyme, was considered a bean oxidize malate [42]. In the group IIb, a protein detected in Red Mexican has a molecular size $(33.3 \mathrm{kDa})$ and isoelectric point $(5.0 \mathrm{pI})$ very similar to those of a glycine-rich cell wall protein in bean (33.4 kDa-5.0 pI) named GRP 1.8, which is expressed in young hypocotyls and excision- 


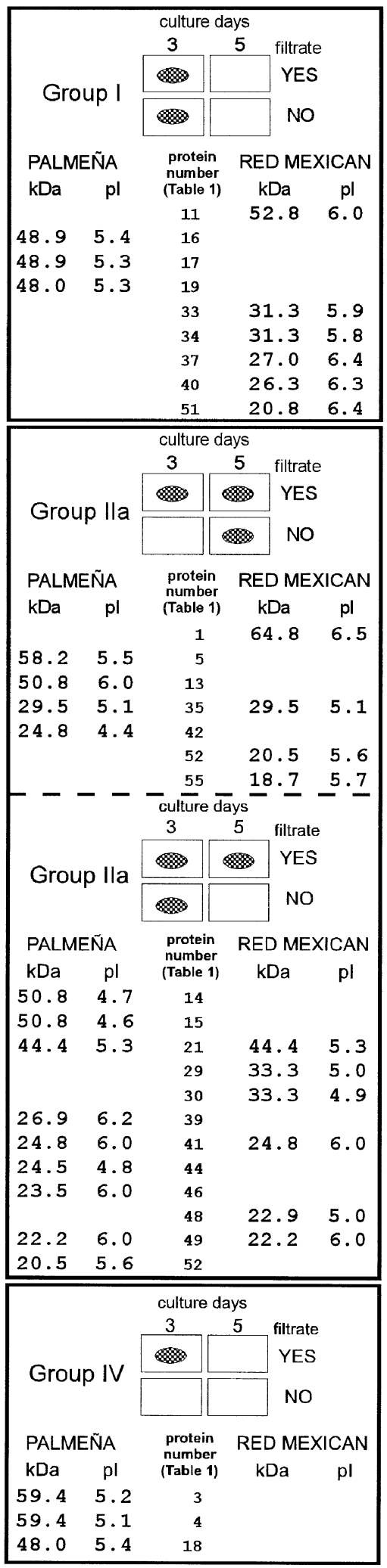

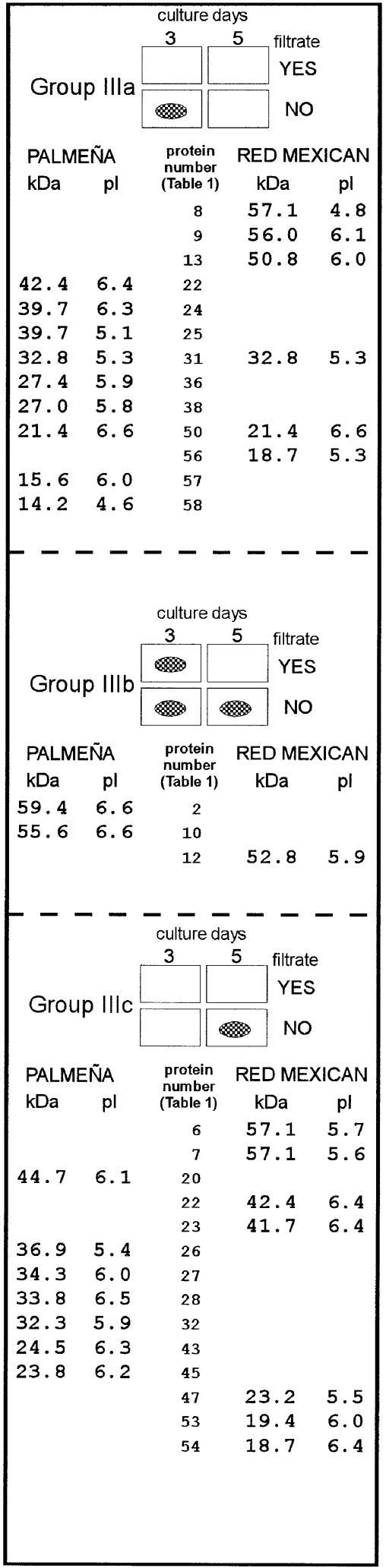

Figure 3. Classification of polypeptides that showed a differential expression along the different in vitro culture conditions used (three and five days of culture in filtratesupplemented or filtrate-free media). Dotted ovals indicate polypeptide presence in the corresponding 2-D PAGE gel. 
wounding transiently induced in old hypocotyl tissue [22]. Nevertheless, relationships between the proteins described by different authors are hard to establish because of the difficulty in comparing the patterns from gel electrophoresis of crude total extracts obtained in different laboratories.

Group III: Polypeptides inhibited by filtrate. These polypeptides are present in explants cultured on the filtrate-free medium either at 3 days (subgroup IIIa) or 5 days (subgroup IIIc) but they are not observed at all when the explants were cultured on the filtrate-supplemented medium. This group also includes two polypeptides observed in explants of Palmeña, and one observed in explants of Red Mexican which were detected after 3 days both on the filtrate-supplemented and filtrate-free medium, but disappeared after 5 days on media with filtrate (IIIb).

Group IV: Polypeptides induced by filtrate in cv. Palmeña. A reduced number of polypeptides (three polypeptides) were only evident in explants of the susceptible cv. Palmeña after 3 days of culture on the medium supplemented with filtrate (MSD-fil). The filtrate of Pseudomonas syringae pv. phaseolicola has been used successfully in in vitro culture as a selective agent given its phytotoxic activity [3]. In our case, the phytotoxic activity present in the filtrate would be the reason for the differential response detected in the cvs. Palmeña and Red Mexican, which are susceptible and resistant respectively, to the infection with the race 1 of $P$. $s$. pv. phaseolicola. Current ideas suggest that the timing and extension of phytoalexin accumulation may lead to compatibility or incompatibility in the interaction between the host and virulent or avirulent races of pathogen [9]. Slusarenko and Longland [35] infecting Red Mexican plants with virulent (race 2) and avirulents (race 1) races of $P$. $s$. pv. phaseolicola observed that the mRNA activities for some polypeptides decrease rapidly during the HR but decrease more slowly in the susceptible reaction. In our case, the induced polypeptides are only observed in the susceptible cultivar (Palmeña). This could be due to the fact that in cv. Red Mexican the response to filtrate was induced earlier or the polypeptide(s) had a more rapid turnover.
In conclusion, our results show that the crude filtrate of Pseudomonas syringae pv. phaseolicola race 1 assayed on in vitro cultured cotyledonary node explants of bean enables us to detect a differential response between Palmeña and Red Mexican, cultivars susceptible and resistant to the race 1 of Pseudomonas syringae pv. phaseolicola, respectively.

Acknowledgements. We thank Professor M. Pérez de la Vega for helpful discussions concerning this manuscript. This work was supported by a Spanish C.I.C.Y.T. research grant (BIO 90-1034) and a doctoral grant to A.I. González from Excma Diputación Provincial de León (Spain).

\section{References}

[1] Antoniw J.F., Ritter C.E., Pierpoint W.S., van Loon L.C., Comparison of three pathogenesis-related proteins from plants of two cultivars of tobacco infected with TMV, J. Gen. Virol. 47 (1980) 79-87.

[2] Antoniw J.F., Kueh J.S.H., Walkey D.G.A., White R.F., The presence of pathogenesis-related proteins in callus of Xanthi-nc tobacco, Phytopath. Z. 101 (1981) 179-184.

[3] Bajaj Y.P.S., Saettler A.W., Effect of halo toxincontaining filtrates of Pseudomonas phaseolicola on the growth of bean callus tissue, Phytopathol. 60 (1970) 1065-1067.

[4] Bauw G., Deloose M., Inze D., Vanmontagu M., Vandekerckhove J., Alterations in the phenotype of plant-cells studied by $\mathrm{NH}_{2}$-terminal amino acid sequence analysis of proteins electroblotted from twodimensional gel separated total extracts, Proc. Nat. Acad. Sci. USA 84 (1987) 4806-4810.

[5] Bell J.N., Dixon R.A., Bailey J.A., Rowell P.M., Lamb C.J., Differential induction of chalcone synthase mRNA activity at the onset of phytoalexin accumulation in compatible and incompatible plant-pathogen interactions, Proc. Nat. Acad. Sci. USA 81 (1984) 3384-3388.

[6] Chang P.F.L., Xu Y., Narasimhan M.L., Cheah K.T., Durzo M.P., Damsz B., Kononowicz A.K., Abad L., Hasegawa P.M., Bressan R.A., Induction of pathogen resistance and pathogenesis-related genes in tobacco by a heat-stable Trichoderma mycelial extract and plant signal messengers, Physiol. Plant. 100 (1997) 341-352. 
[7] Cramer C.L., Bell J.N., Ryder T.B., Bailey J.A., Schuch W., Bolwell G.P., Robbins M.P., Dixon R.A., Lamb C.J., Co-ordinated synthesis of phytoalexin biosynthetic enzymes in biologically-stressed cells of bean (Phaseolus vulgaris L.), EMBO J. 4 (1985) 285-289.

[8] De Tapia M., Bergmann P., Awade A., Burkard G., Analysis of acid extractable bean leaf proteins induced by mercuric chloride treatment and alfalfa mosaic virus infection: Partial purification and characterization, Plant Sci. 45 (1986) 176-177.

[9] Dixon R.A., Lamb C.J., The specificity of plant defenses, Nature 283 (1980) 135-136.

[10] Dixon R.A., Dey P.M., Lamb C.J., Phytoalexins: Molecular biology and enzymology, Adv. Enzymol. Relat. Areas Mol. Biol. 55 (1983) 1-135.

[11] Dong J.Z., Perras M.R., Abrams R., Dunstan D.I., Gene expression patterns, and uptake and fate of fed ABA in white spruce somatic embryo tissues during maturation, J. Exp. Bot. 48 (1997) 277-287.

[12] Dunn M.J., Two-dimensional gel electrophoresis of proteins, J. Chromatogr. 418 (1987) 145-185.

[13] Edington B.V., Lamb C.J., Dixon R.A., cDNA cloning and characterization of a putative $1,3-\beta-\mathrm{D}$-glucanase transcript induced by fungal elicitor in bean cell suspension cultures, Plant Mol. Biol. 16 (1991) 81-94.

[14] Fernández-Caso M., Peláez M.I., Ruiz M.L., Onset of in vitro morphogenic response and protein pattern changes in Phaseolus vulgaris L., J. Plant Physiol. 149 (1996) 757-761.

[15] Gabriel D.W., Ellingboe A.H., High resolution two-dimensional electrophoresis of protein from congenic wheat lines differing by single resistance genes, Physiol. Plant Pathol. 20 (1982) 349-357.

[16] Grosset J., Marty I., Chartier Y., Meyer Y., mRNAs newly synthesized by tobacco mesophyll protoplasts are wound-inducible, Plant Mol. Biol. 1 (1990) 485-496.

[17] Hammerschlag F.A., Werner D.J., Ritchie D.F., Stability of bacteria leaf-spot resistance in peach regenerants under in vitro greenhouse and field conditions, Euphytica 76 (1994) 101-106.

[18] Hartman C.L., Secor G.A., Venette J.R., Albaugh D.A., Response of bean calli to filtrate from Pseudomonas syringae pv. phaseolicola and correlation with whole plant disease reaction, Physiol. Mol. Plant Pathol. 28 (1986) 353-358.

[19] Heitz T., Segond S., Kauffmann S., Geoffroy P., Prasad V., Brunner F., Fritig B., Legrand M., Molecular characterization of a novel tobacco pathogenesis related (PR) protein- a new plant chitinase/lysozyme, Mol. Gen. Genet. 245 (1994) 246-254.

[20] Jensen J.H., Goss R.W., Physiological resistance to halo-blight in beans, Phytopathol. 32 (1942) 247-258.

[21] Jung J.L., Maurel S., Fritig B., Hahne G., Different pathogenesis-related-proteins are expressed in sunflower (Helianthus annuus L.) in response to physical, chemical and stress factors, J. Plant Physiol. 145 (1995) 153-160.

[22] Keller B., Sauer N., Lamb C.J., Glycine-rich cell wall proteins in bean: gene structure and association of the protein with the vascular system, EMBO J. 7 (1988) 3625-3633.

[23] King E.O., Ward M.K., Raney D.E., Two simple media for the demonstration of pyocyanin and fluorescin, J. Lab. Clin. Med. 44 (1954) 301-307.

[24] Lipkin L.E., Lemkin P.F., Data-base techniques for multiple two-dimensional polyacrylamide gel electrophoresis analyses, Clin. Chem. 26 (1980) 1403-1412.

[25] Maniatis T., Fritsch E.F., Sambrook J., Molecular cloning. A laboratory manual, Cold Spring Harbour Laboratory, 1982.

[26] Merril C.R., Goldman D., Sedman S.A., Ebert M.H., Ultrasensitive stain for proteins in polyacrylamide gels shows regional variation in cerebrospinal fluid proteins, Science 211 (1981) 1437-1438.

[27] Mohamed F., Sehgal O.P., Characteristics of pathogenesis-related proteins induced in Phaseolus vulgaris cv. pinto following viral infection, J. Phytopathol. 145 (1997) 49-58.

[28] Murashige T., Skoog F., A revised medium for rapid growth and bioassays with tobacco tissue cultures, Physiol. Plant 15 (1962) 151-158.

[29] O'Farrel P.H., High resolution two-dimensional electrophoresis of proteins, J. Biol. Chem. 250 (1975) 4007-4021.

[30] Rushton P.J., Somssich I.E., Transcriptional control of plants genes responsive to pathogens, Curr. Opin. Plant Biol. 1 (1998) 311-315.

[31] Sako N., Stahman M.A., Multiple molecular forms of enzymes in barley leaves infected with Erysphe graminis f sp. hordei, Physiol. Plant Pathol. 2 (1972) 217-226.

[32] Santoni V., Delarue M., Caboche M., Bellini C., A comparison of two-dimensional electrophoresis data with phenotypical traits in Arabidopsis leads to the iden- 
tification of a mutant (cri1) that accumulates cytokinins, Planta 202 (1997) 62-69.

[33] Scheel D., Resistance response physiology and signal transduction, Curr. Opin. Plant Biol. 1 (1998) 305-310.

[34] Sehgal O.P., Pathogenesis-related proteins in lima bean leaves infected with tobacco ringspot virus and their distribution within and around local lesions, Plant Cell Rep. 12 (1992) 55-59.

[35] Slusarenko A.J., Longland A., Changes in gene activity during expression of the hypersensitive response in Phaseolus vulgaris cv. Red Mexican to an avirulent race 1 isolate of Pseudomonas syringae pv. phaseolicola, Physiol. Mol. Plant Pathol. 29 (1986) 79-94.

[36] Taylor J.D., Teverson D.M., Allen D.J., PastorCorrales M.A., Identification and origin of races of Pseudomonas syringae pv. phaseolicola from Africa and other bean growing areas, Plant Pathol. 45 (1996) 469-478.

[37] Vaquero F., Robles C., Ruiz M.L., A method for long-term micropropagation of Phaseolus coccineus L., Plant Cell Rep. 12 (1993) 395-398.

[38] Vögeli U., Meins F., Boller T., Co-ordinated regulation of chitinase and $\beta$-1,3-glucanase in bean leaves, Planta 174 (1988) 364-372.
[39] Vurro M., Ellis B.E., Effect of fungal toxins on induction of phenylalanine ammonia-lyase activity in elicited cultures of hybrid poplar, Plant Sci. 126 (1997) 29-38.

[40] Walker J.C., Patel P.N., Splash dispersal and wind as factors in epidemiology of halo-blight of bean, Phytopathol. 54 (1964) 140-141.

[41] Walter M.H., Grima-Pettenati J., Grand C., Boudet A.M., Lamb C.J., Cinnamyl-alcohol dehydrogenase, a molecular market specific for lignin synthesis: cDNA cloning and mRNA induction by fungal elicitor, Proc. Nat. Acad. Sci. USA 86 (1988) 5546-5550.

[42] Walter M.H., Liu J.W., Grand C., Lamb C.J., Hess D., Bean pathogenesis-related (PR) proteins deduced from elicitor-induced transcripts are members of a ubiquitous new class of conserved PR proteins including pollen allergens, Mol. Gen. Genet. 222 (1990) 353-360.

[43] Walter M.H., Grima-Pettenati J., Grand C., Boudet A.M., Lamb C.J., Extensive sequence similarity of the bean CAD4 (cinnamyl-alcohol dehydrogenase) to maize malic enzyme, Plant Mol. Biol. 15 (1990) 525-526.

[44] Wilkins M.R., Williams K.L., The extracellular matrix of the Dictyostelium dicoideum slug, Experientia 51 (1995) 1189-1196. 